\title{
Article \\ Improving Transboundary Drought and Scarcity Management in the Iberian Peninsula through the Definition of Common Indicators: The Case of the Minho-Lima River Basin District
}

\author{
Rodrigo Maia ${ }^{1,2, *(1)}$, Miguel Costa ${ }^{1,2}$ and Juliana Mendes ${ }^{1,2}$ a \\ 1 Civil Engineering Department, Hydraulics, Water Resources and Environment Division, \\ Faculty of Engineering, University of Porto, Rua Roberto Frias, 4200-465 Porto, Portugal; \\ mapcosta@fe.up.pt (M.C.); juliana@fe.up.pt (J.M.) \\ 2 Interdisciplinary Centre of Marine and Environmental Research (CIIMAR), University of Porto, \\ Terminal de Cruzeiros do Porto de Leixões, Avenida General Norton de Matos, \\ 4450-208 Matosinhos, Portugal \\ * Correspondence: rmaia@fe.up.pt
}

check for updates

Citation: Maia, R.; Costa, M.;

Mendes, J. Improving Transboundary Drought and Scarcity Management in the Iberian Peninsula through the Definition of Common Indicators: The Case of the Minho-Lima River Basin District. Water 2022, 14, 425. https://doi.org/10.3390/w14030425

Academic Editors: Athanasios

Loukas and Luis Garrote

Received: 31 December 2021

Accepted: 27 January 2022

Published: 29 January 2022

Publisher's Note: MDPI stays neutral with regard to jurisdictional claims in published maps and institutional affiliations.

Copyright: (C) 2022 by the authors. Licensee MDPI, Basel, Switzerland. This article is an open access article distributed under the terms and conditions of the Creative Commons Attribution (CC BY) license (https:// creativecommons.org/licenses/by/ $4.0 /)$.

\begin{abstract}
Drought is one of the most damaging natural hazards in the Iberian Peninsula, causing varied socioeconomic and environmental impacts. To prevent these impacts, there must be close cooperation between Portugal and Spain, as the two countries share five river basins. However, regarding drought planning and management the two countries are clearly in different stages. Portugal approved a national drought plan in 2017, while Spain has already had drought plans in place for all River Basin Districts since 2007 and approved an updated version of these plans in 2018. The Spanish drought plans currently in place foresee two sets of indicators: prolonged drought and scarcity indicators. This paper presents the definition of similar indicators for the Portuguese part of the shared Minho and Lima river basins, according to European guidelines and in common with Spain, with the aim of developing a joint international drought management plan for these basins. For the period from October 1980 to September 2017, the comparison of the indicators obtained for the Portuguese parts of the basins with the corresponding Spanish ones shows a similarity in the occurrence of drought and scarcity in both parts of the basins, although with a higher prevalence of scarcity situations in the Lima Spanish part. This work was developed in close collaboration with the River Basin District competent authorities of both countries, aiming to be a prototype for the definition of new and comparable drought and operational scarcity indicators. Therefore, this work is a starting point for the creation of common tools for integrated drought management of transboundary basins in the IP.
\end{abstract}

Keywords: prolonged drought; scarcity; indicators; transboundary river basins; Iberian Peninsula

\section{Introduction}

Drought and water scarcity have always been situations of concern. While drought is a natural phenomenon caused by an abnormal precipitation deficit over a certain region and period of time, water scarcity is a result of human action, referring to an insufficient water availability to satisfy water demands for different socio-economic uses [1]. From an operational perspective (as mostly considered for definition of common indicators), scarcity is considered a temporal problem of lack of water resources. Nonetheless, water scarcity can also be understood as the long-term unsustainable use of water resources, determined by social and political processes [2,3].

Drought and water scarcity events commonly coexist and are interdependent in a same region, making the distinction between them a complex process. Moreover, water scarcity enhances regional vulnerability to drought effects [3,4].

The increasing frequency and intensity of such phenomena, which are expected to worsen from climate change, have been leading to an increasing and urgent need to establish 
specific policies and management measures to deal with the associated risks and the mitigation of the related effects $[5,6]$. These issues become even more relevant in watersheds shared by different countries, since conflicts (defined by opposing national interests and/or policies) over water use tend to be more pronounced, and the harmonization of water policies and bilateral agreements and sustainable water use is required.

At the European Union (EU) level, in order to achieve the environmental objectives established for the protection of water bodies, the Water Framework Directive (WFD) [7] states that, within a river basin shared by different countries, where the use of water may have transboundary effects, water management should be coordinated for the whole of the River Basin District (RBD). In this context, the WFD stipulates that Member States (MSs) shall ensure coordination with the aim of producing a single international River Basin Management Plan (RBMP). In case that is not possible, the WFD envisages that the MSs develop individual but coordinated RBMPs for each territorial part of the river basin. This directive corresponds to greater country responsibility and interference in water management of shared river basins in order to achieve WFD provisions of good environmental status, in line with increasing concern with water quality, namely by southern Member States [8].

One of the purposes of the WFD is to contribute to the mitigation of drought effects. However, the WFD states that in the case of exceptional natural conditions, such as a prolonged drought, the temporary deterioration of water quality will not breach the Directive requirements (Article 4.6). Although "water scarcity" is not directly mentioned in the WFD, its frame is implicit across it, namely by highlighting (Article 11) that MSs shall ensure the establishment of measures to promote efficient and sustainable water use.

To deal with more specific situations, namely for the mitigation of drought and scarcity effects, the WFD highlights the possibility of complementing the RBMPs through special programs and management plans (e.g., drought management plans-DMPs), which should, whenever possible, also be jointly set by the States involved in the case of international river basins (Article 13.5). Despite not being mandatory, the development of DMPs has been strongly recommended, namely by means of the EU Communications on Drought and Water Scarcity [9-11] and corresponding follow-up reports. In one of those reports [12] the importance and the need of separate indicators to evaluate drought and water scarcity situations is enhanced.

In the Iberian Peninsula (IP), drought is one of the most damaging natural hazards, causing wide-ranging socioeconomic and environmental impacts, which are prospected to continue the recent years' aggravation trends due to climate change. To prevent impacts from drought, close cooperation between Portugal and Spain is required, namely regarding water and drought planning and management, as the two countries share five river basins (Minho/Miño, Lima/Limia, Douro/Duero, Tejo/Tajo and Guadiana) that cover $45 \%$ of the Iberian territory (Figure 1). This issue is particularly relevant for Portugal, as $64 \%$ of its territory corresponds to shared river basins, with the Portuguese part located downstream, rendering the country extremely vulnerable to the quantity and quality of water flowing from Spain [13].

In 1998, the two countries signed the Convention on Cooperation for PortugueseSpanish River Basin Protection and Sustainable Use (commonly referred to as the Albufeira Convention), which has been in force since 2000 [14] and was revised in 2008 [15] under the WFD principles. The convention defines the framework for bilateral cooperation to promote and protect the good status and the sustainable use of water resources in the shared river basins, as well as actions to contribute to mitigate the effects of floods, droughts and water scarcity situations.

Under the Albufeira Convention, two institutional bodies were constituted: the Parts Conference (Article 21) and the Commission for Convention Development and Appliance (CADC) (Article 22). The first has mainly a political role and guarantees bilateral cooperation at the highest levels, its representatives being appointed by the Government of each country. The CADC has an operational, deliberative, consultative and supervisory 
role, having the responsibility to ensure compliance with the Convention obligations. The CADC is composed of two delegations, one from each country [14].

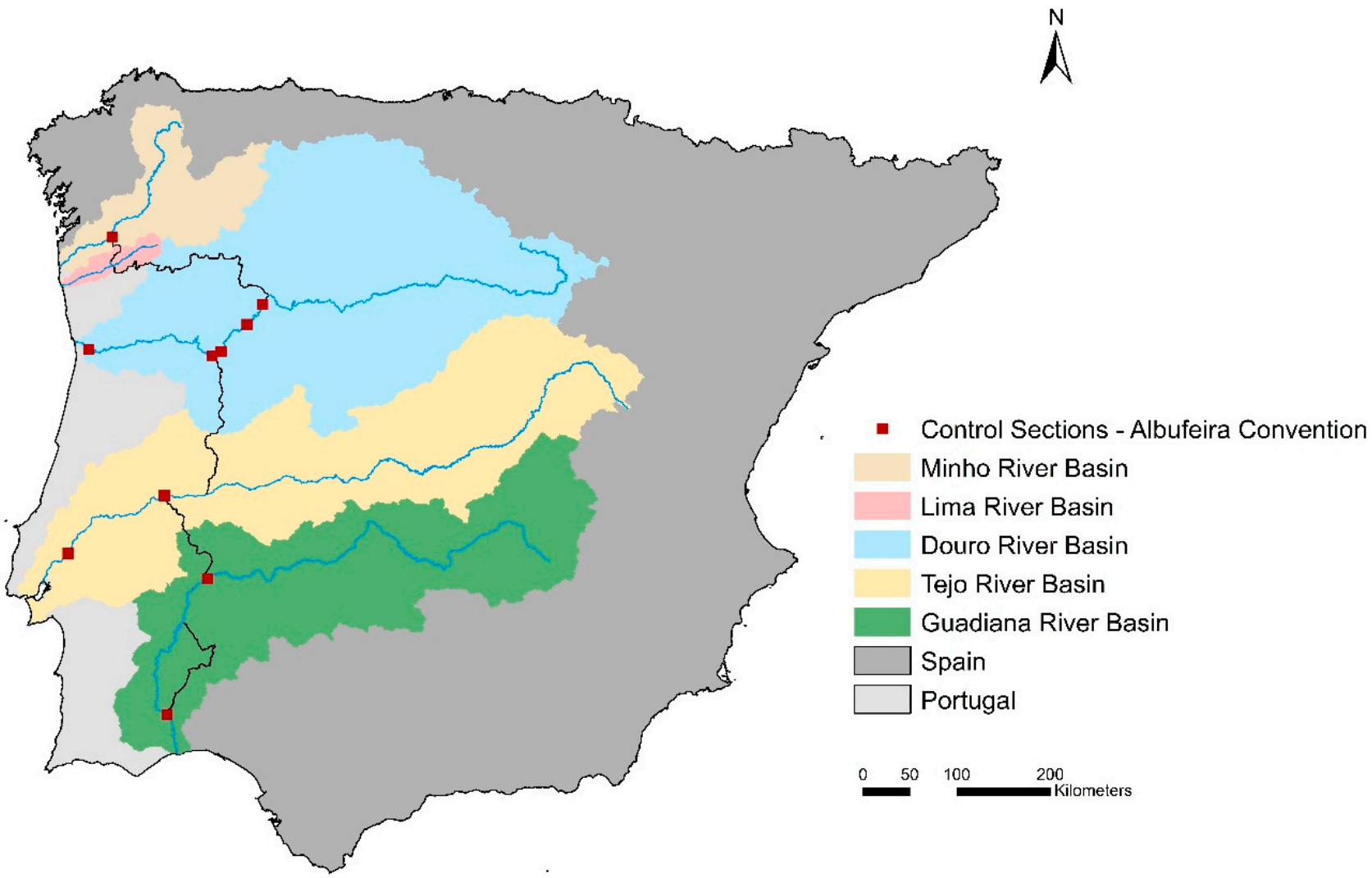

Figure 1. Transboundary river basins in the Iberian Peninsula and respective flow control sections under the Albufeira Convention.

In this context, and in order to secure good water conditions and the current and predictable uses, the Albufeira Convention (AC) defined a minimum flow regime (MFR) at the border sections (and bordering/international river stretches) of each of the PortugueseSpanish shared river basins (except Lima) (Figure 1). Currently, as stated in the revised version of the convention [15], the MFR consists of minimum volumes of water to be guaranteed at the control (namely bordering) sections: annually and quarterly, for all (4) shared basins; weekly for the two major basins (Douro/Duero and Tejo/Tajo rivers), and; for the southern basin (Guadiana river basin), mean diary flow at the bordering section at the entrance of the Guadiana river in Portugal (Badajoz weir) and at the upstream section (Pomarão) of the estuarine and lower bordering stretch between the two countries. Nevertheless, these flow regimes are not applicable under exceptional drought conditions, those defined by means of cumulative precipitation thresholds and also (only for Guadiana river) on reservoir volumes, based on the weighted values of the referenced monitoring stations in the Spanish part of each basin [14,15].

Moreover, according to Article 19 of the Convention, the parties: (i) should coordinate their actions to control and to prevent drought and scarcity situations and (ii) should define the nature of the exceptions and the establishment of exceptional mechanisms, which can include, among others: (a) the definition of the conditions in which the exceptional measures can be applied and (b) the possible use of indicators that characterize, in an objective way, the drought and scarcity situations. Under the above-referred context and Albufeira Convention principles, the current MFR values and time frame continue to be considered provisional, insufficient and requiring of further revision $[16,17]$.

Spain approved and has implemented drought plans in all the River Basin Districts since 2007 [18]. The 2007 Spanish drought plans were already been revised and approved in 
2018 [19]. In the 2018 versions (e.g., [20]), two types of indicators are defined: a Prolonged Drought Indicator (PDI) and a Water Scarcity Indicator (SI).

Portugal approved a national drought plan in 2017, by which two types of drought situations (agrometeorological and hydrological) are identified through the use of simple variables (or standardized indexes), like precipitation, stored dam reservoir volumes, piezometric levels and soil moisture [21]. Specific DMPs by River Basin District are envisaged but still not active.

Considering these national differences, in order to minimize water conflicts and prevent drought-related impacts (e.g., in 1994/95, in the Guadiana river basin, the affluences to Portugal were actually null for six months [22]. In 2019, some Portuguese parts of the Tejo river basin dried out due to Spanish water management, contributing to the water quality degradation in the Portuguese part [23], which led to political contact between the two Government representatives, namely the Environmental Ministers [24]), several efforts should be made by the two countries to adopt coordinated and/or possible joint drought management and planning through the establishment of standard and/or common approaches, in the light of the AC and WFD. One of the most important approaches that should be enforced is the definition of common indicators that characterize, in an objective way, the drought and scarcity situations [13,22,25].

In this sense, the Spanish methodology, by using separate indicators for those situations, presents a good basis for the establishment of a common system of indicators for the Iberian Peninsula in order to achieve a better integration with the WFD and AC goals, representing a step forward in the implementation of European Water Policies regarding drought management and planning.

The purpose of the presented work was the definition of prolonged drought and scarcity indicators for the Portuguese parts of the shared Minho and Lima river basins, in common with the Spanish parts of the basins, as the basis for the joint international DMP for these basins. In fact, following this work, this DMP is already in the stage of discussion for approval by the Portuguese and Spanish RBD authorities (respectively, APA-Agência Portuguesa do Ambiente and CHMS-Confederación Hidrográfica del Miño-Sil).

The paper describes the procedure used in the definition of the indicators for the Portuguese parts of the basins, as well as its comparison with the corresponding Spanish indicators, for a period from October 1980 to September 2017. The work allowed us to assess the applicability of a common system of indicators for any Portuguese-Spanish transboundary river basin's drought and scarcity management.

This work is intended to be a prototype for the definition of new and similar drought indicators to be applied in common by Portugal and Spain in the shared river basins, and was developed in close collaboration with the Portuguese Minho and Lima RBD and the corresponding Spanish RBD authorities under the scope of the RISC-ML project [26].

\section{Materials and Methods}

\subsection{Study Area}

The study area encompasses the Minho and Lima river basins, which are two of the five international river basins shared between Portugal and Spain that are integrated into a single international RBD, in accordance with the WFD. The major part of the RBD total area is in Spain, and only about $10 \%$ of that area is located in Portugal, that corresponding to $48 \%$ of Lima and $5 \%$ of Minho total river basins area (respectively, $2522 \mathrm{~km}^{2}$ and $17,067 \mathrm{~km}^{2}$ ) [27].

Regarding water management, in Portugal, the Minho and Lima river basins (Portuguese parts) integrate and form the Minho-Lima RBD (RBD1), with each river basin part being considered a specific and independent hydrological analysis unit. In Spain, the two river basins' Spanish parts constitute the Miño-Sil RBD, which is divided in 6 territorial operational management units (TMUs) (5 in Minho, 1 in Lima), as shown in Figure 2. 


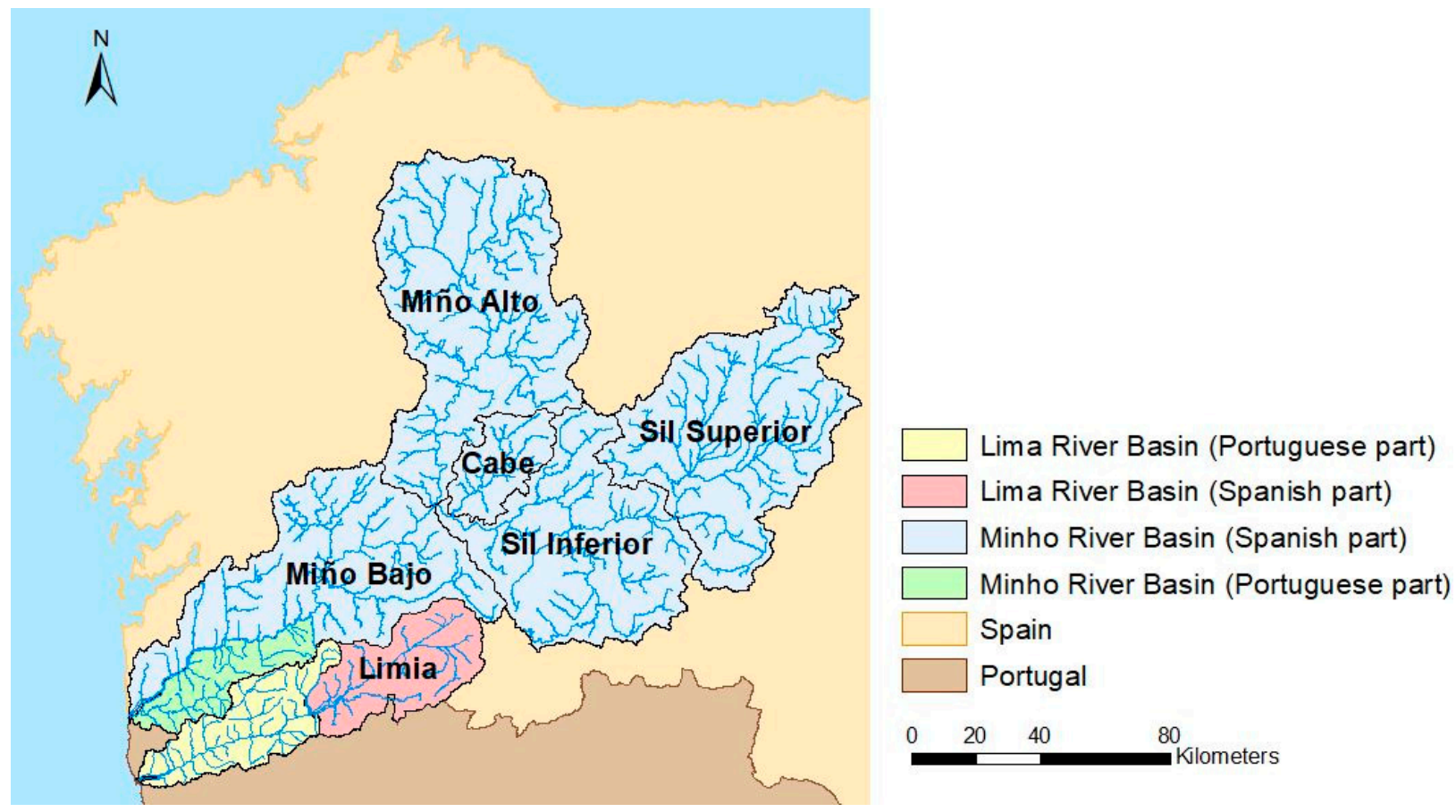

Figure 2. Portuguese and Spanish parts of the Minho and Lima river basins, with their corresponding Spanish territorial management units (TMUs) identified.

\subsection{Methodology}

In this work, the definition of the Prolonged Drought and Scarcity indicators for the Portuguese part of Minho and Lima river basins was carried out according to the methodology defined in the current version of the Special Drought Plan of the Spanish part of the Miño-Sil River Basin District (2018 PES-MS) [20], in agreement with the technical instruction provided by the Ministry for the Ecological Transition of Spain [28].

A prolonged drought is a natural, persistent and intense situation of reduction of precipitation, produced by unusual circumstances, with influence on the runoff. The Prolonged Drought Indicator (PDI) should identify, temporally and territorially, runoff reduction by natural causes, independently of human water resources management. Therefore, the aim of the PDIs is to establish the threshold for compliance with the environmental flow regime defined in the RBMPs and to limit the occurrence of situations of temporary deterioration of water bodies quality only to prolonged drought natural phenomena situations (and not to scarcity situations), as set out in the WFD [6,28]. According to Article 18 of the Spanish Hydrological Planning Regulation [29], a prolonged drought situation allows the justified reduction of the environmental flows of water bodies established in the RBMPs.

A scarcity situation is defined as a temporal problem of lack of resources to meet the water demands associated with the different socioeconomic uses of water. Thus, the Scarcity Indicator (SI) is based on the relationship between the availability of resources and water demands, identifying the inability of the resources to meet the demands. Consequently, it serves as an instrument of assistance in decision making related to the management of water resources. The SI is an operational indicator, aiming at the progressive triggering of measures in order to postpone or avoid the occurrence of the most severe stages of scarcity, mitigating their adverse impacts to the several water uses [6,28].

The general methodology used for the definition of each of the two indicators is schematized in Figure 3. 


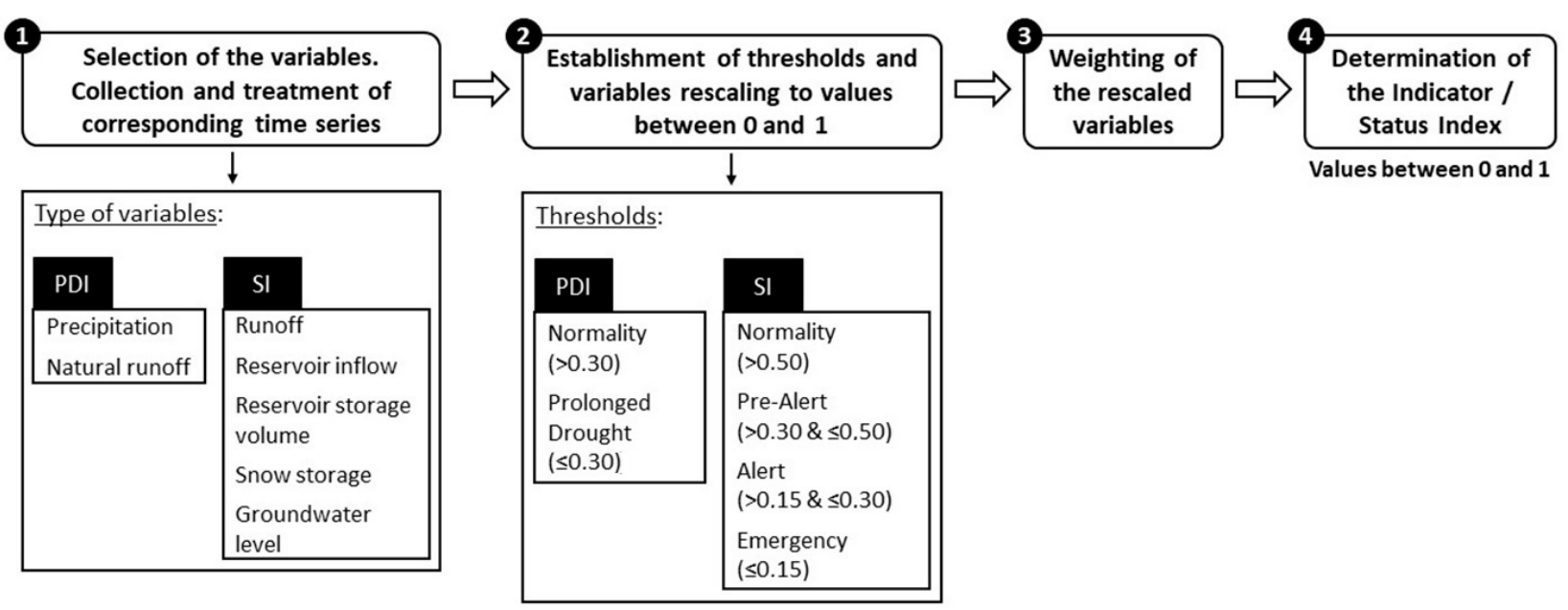

Figure 3. General methodology for the definition of both indicators (PDI and SI) (adapted from [20]).

The procedure begins with the selection of the hydrometeorological variables for each defined territorial unit of analysis. For the PDI, two types of variables may be considered: precipitation and runoff in natural regime. For the SI, the variables may be of various types, including runoff, reservoir inflow, reservoir storage volume, snow storage, and groundwater levels. These variables can be represented by their own values or by the corresponding standardized indices (e.g., SPI).

After the selection of the variables, they are rescaled into dimensionless variables varying between 0 and 1 . In order for the rescaling of the variables to be performed, both indicators require a reference time series to be considered. The period between October 1980 and September 2012 was considered for all the reference series displayed in the 2018 PES-MS [20]. This 32-year hydrological monthly time series served as a sample to perform a statistical analysis of the data records, identifying the characteristics of the humid, normal and dry periods. Therefore, it allowed us to establish the predominant values/characteristics in the TMUs and enabled the analysis and characterization of later events by comparing it with the values of the reference series.

For both the Prolonged Drought and Scarcity indicators, the rescaling step requires the establishment of monthly thresholds for each of the 12 months of the year. One threshold was defined for PDI, corresponding the occurrence of prolonged drought, and three thresholds were defined for SI, corresponding to different limits of water scarcity stages (pre-alert, alert and emergency).

Subsequently, the rescaled variables were aggregated in a weighted way, producing a single indicator (also entitled as a Status Index, or "Indice de Estado" in Spain). This has a great advantage relative to the use of other type of indicators, namely simple standard indexes, because it enables to compare the indicator's results among different basins, despite their diverse geographical, climatic, water demands and other specific characteristics [6].

As referred before (in Section 1), the territorial units most suitable for the analysis and management of the two situations (prolonged drought and water scarcity) may be different. In the case of the 2018 PES-MS, the territorial units of analysis used for both indicators' definitions were those presented in Figure 2. Similarly, for the work developed and presented here, it was considered that the territorial units used for the Prolonged Drought and Scarcity indicator definitions in the Portuguese parts of the Minho and Lima river basins corresponded to their full country areas (also pictured in Figure 2).

In the Portuguese parts of the Minho and Lima river basins, the PDI and SI were defined for the period from October 1980 to September 2017, taking as reference time series the period from October 1980 to September 2012, such as in the 2018 PES-MS [20]. For the Lima river basin, the SI was defined for the period from October 1993 to September 2017, 
taking as reference time series the period from October 1993 to September 2012, as will be reported below (in Section 2.2.2).

The indicators obtained to the Portuguese parts of the Minho and Lima river basins were then compared, for each basin, with those obtained in the corresponding Spanish parts of the basins. In this context, the Portuguese parts of the Lima basin were compared with the ones defined to the Limia TMU. For the Minho basin, a similar comparison was made with the Miño-Bajo TMU, as this was the nearest territorial unit adjacent to the Portuguese part (see Figure 2).

The specific methodology used to define the Prolonged Drought and the Scarcity indicators, respectively, in the Portuguese parts of the Minho and Lima river basins are described below (in Sections 2.2.1 and 2.2.2), in more detail.

\subsubsection{Prolonged Drought}

In the Portuguese part of the Minho and Lima river basins, as considered in the Spanish part of the basins, two variables were considered in the definition of the PDI: (i) average monthly precipitation in the whole basin; and (ii) natural monthly runoff in one hydrometric station of the river basin hydrographic network.

Precipitation and runoff data recorded at stations of the Portuguese National Water Resources Information System (SNIRH in Portuguese acronym) monitoring network were used.

The monthly average precipitation in each Portuguese basin region was calculated through the Thiessen method, using the available data of the existing meteorological stations.

The hydrometric station chosen to represent the natural monthly runoff in the Portuguese part of the Lima river basin was "Pontilhão de Celeiros", located on Vez river (tributary at the right bank of the Lima river), its section having a sub-basin area of about $170 \mathrm{~km}^{2}$. For the Minho hydrographic basin, the selected hydrometric station was "Segude", which corresponds to a sub-basin with an area of nearly $130 \mathrm{~km}^{2}$ located on the Mouro river (tributary at the left bank of the Minho river) (Figure 4). To fill the missing data in the hydrometric stations, hydrological modeling using HEC-HMS software in a continuous simulation mode based on daily precipitation was performed.

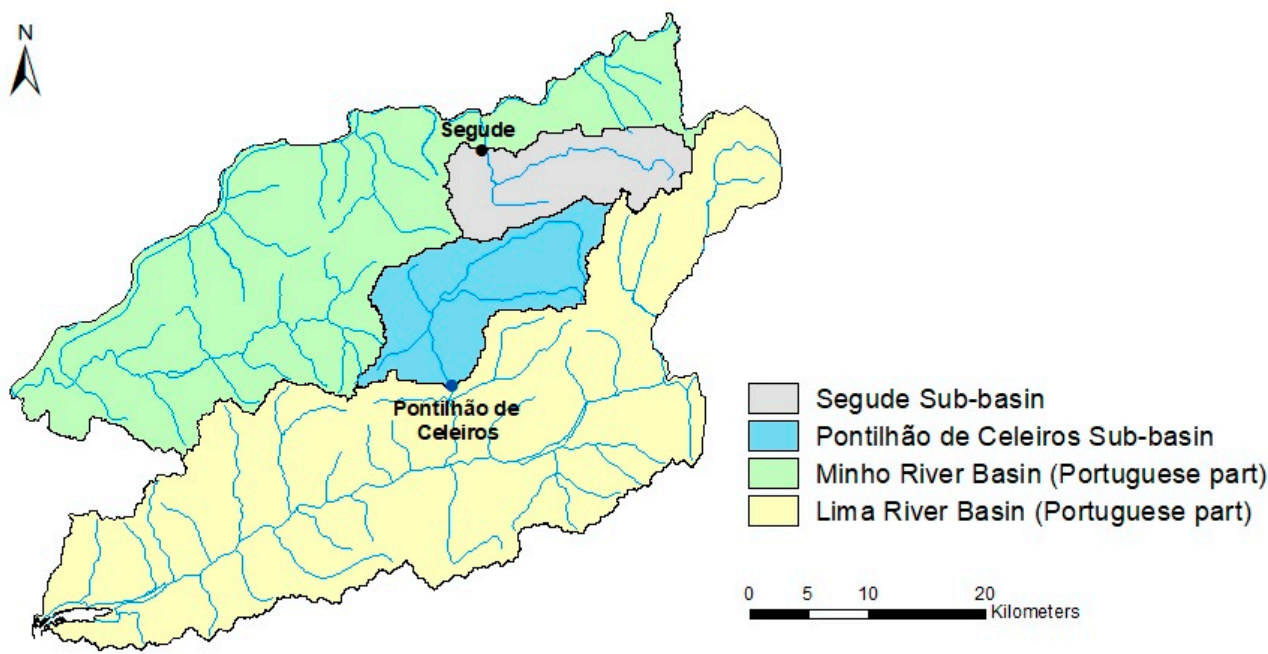

Figure 4. Relative location of the sub-basins at the sections of the hydrometric stations of "Pontilhão de Celeiros" (in the Lima river basin) and "Segude" (in the Minho river basin).

The two required variables (precipitation and natural runoff) were computed through the accumulated monthly records from the previous 12 months. Based on these, the two variables were transformed and translated into standardized values, namely, the Standardized Precipitation Index $\left(\mathrm{SPI}_{12}\right)$ for the variable precipitation, and the Standardized Runoff Index $\left(\mathrm{SRI}_{12}\right)$ for the variable natural runoff. For this purpose, the SPI and SRI 
were calculated by adjusting the precipitation and runoff data, respectively, to a gamma distribution [30].

After the selection and treatment of the variables, the SPI and SRI values were rescaled into dimensionless values ranging from 0 to 1 . This rescaling process was achieved based on the following monthly reference values for each of the 12 months of the year:

- 1.0: Maximum value of SPI/SRI in the reference series (October 1980-September 2012);

- 0.5 : Median value of SPI/SRI in the reference series (October 1980-September 2012);

- 0.3 : Value of SPI/SRI equal to -1.2813 (cumulative probability of occurrence of $10 \%$ ): value established as the prolonged drought threshold;

- 0.0: Minimum value in the reference series (October 1980-September 2012).

After rescaling, the two variables were aggregated, in a weighted way (considering $60 \%$ for the SPI and $40 \%$ for the SRI), resulting in the PDI. The referred threshold and the weighing values were the same used by Spain in the 2018 PES-MS [20], defined considering the comparison with the historical drought events in the Spanish part of the two basins. In accordance, values below 0.3 indicate the existence of a prolonged drought situation, whereas values above 0.3 indicate a situation of normality.

\subsubsection{Scarcity}

As for the PDI, the first step was the selection and treatment of the variable, or sets of variables, in each basin, that were considered the most representative of the availability of the water resources required to satisfy the different water demands. This selection was made considering the characterization and location of the most significant water demands and also the location of the water abstraction sources to meet those demands, namely, those related to urban water supply, agriculture, industry and tourism. In the Spanish part, the main water demands considered were relative to urban water supply and agriculture. In the Portuguese part of the Lima and Minho river basins, all demands (including agricultural) were not relevant compared to urban water supply, thereby only urban water demands were considered. In the two basins, although water is captured from surface and groundwater bodies, the main sources are surface water bodies.

In the Portuguese part of the Lima river, inflow to the Touvedo dam, located on the Lima river (Figure 5) was chosen as the variable representative of water availability. The Touvedo reservoir serves as the water abstraction source for the urban supply of a large cluster, including the main counties of the Lima river basin, namely Arcos de Valdevez, Ponte da Barca, Ponte de Lima, Viana do Castelo, as well for two counties of the Minho river basin, Caminha and Vila Nova de Cerveira.

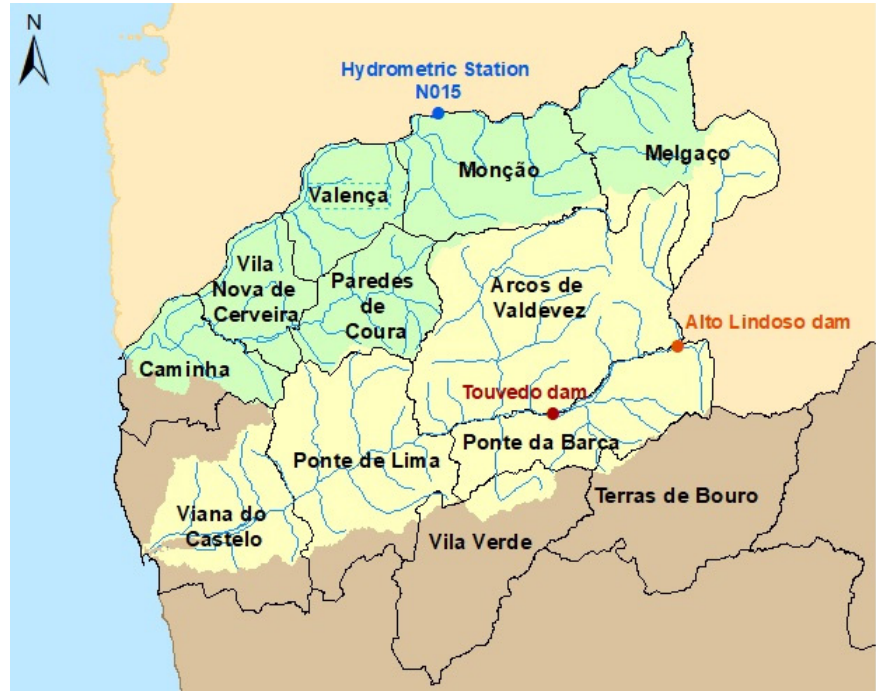

\section{Counties}

Minho River Basin (Portuguese part)

Lima River Basin (Portuguese part)

Portugal

Spain

Figure 5. Counties of the Minho and Lima river basins and locations of the Touvedo dam (Lima) and hydrometric station N015-Rio Miño en Salvaterra do Miño (Minho). 
As the Touvedo reservoir was only built in 1993, for the Lima river basin the SI analysis was carried out for the period from October 1993 to September 2017.

In the Minho river basin, the most important water abstraction source to urban supply is the Troporiz abstraction, which supplies Melgaço, Monção and Valença counties. Therefore, the variable selected to assess scarcity situations in the Portuguese part was the Spanish hydrometric station "N015-Rio Miño en Salvaterra do Miño", located in the Minho river (Figure 5), just $5 \mathrm{~km}$ upstream of the Troporiz abstraction.

In addition to the urban water supply demands, environmental flows associated to the Touvedo dam and to the Minho river abstraction section were also considered. Regarding the Minho river, the stretch where Spanish hydrometric station N015 is located was found to have two different environmental flow regimes definitions once compared of the two countries' definitions.

In fact, Portugal and Spain have adopted two different approaches in the development of the RBMPs, namely for the shared river basins parts: Spain defined environmental flows for all river stretches, while Portugal defined environmental flow regimes only for "heavily modified" water bodies located downstream of reservoirs [27,31-33]. Each country also uses different methods to define environmental flows, which, in addition to the different approaches mentioned above, could lead (namely as referred for Minho river) to a singular transboundary river body having two different environmental flow regime definitions.

In this study, the environmental flow regime considered was the one defined in the Spanish RBMP for the Minho river stretch where the water abstraction is located, since it is larger and thus consequently more challenging to satisfy in situations of scarcity.

The different scarcity situations considered were: Normality (absence of scarcity), Pre-alert (moderate scarcity), Alert (severe scarcity) and Emergency (serious scarcity). The corresponding monthly thresholds were defined for each of the months of the year based on the urban water supply demands considered for both territorial units and also considering the corresponding environmental flow regime, as follows:

- Pre-alert: median value of the reference series inflows per month;

- Alert: minimum inflow required to satisfy water demands and the environmental flows regime;

- Emergency: minimum inflow to satisfy water demands and $50 \%$ of the environmental flow regime.

Once the scarcity thresholds were defined, the variables were rescaled into dimensionless values between 0 and 1 , based on the following reference values:

- 1 : maximum value of the reference series inflows per month;

- 0.5 : Pre-Alert threshold;

- 0.3 : Alert threshold;

- 0.15: Emergency threshold;

- 0 : minimum value of the reference series inflows per month. If the minimum value is greater than any one of the Emergency thresholds, the value 0 will correspond to the minimum Emergency threshold.

Since, in this case, only one variable was chosen to characterize scarcity situations (i.e., weighting factor equal to one) for each of the two basins, the rescaling of the variable resulted in the definition of the SI, to which the different situation range limits corresponded: values between 1 and 0.5 represented a situation of normality; values between 0.5 and 0.3 corresponded to a Pre-Alert situation; values between 0.3 and 0.15 represented an Alert situation; and values below 0.15 corresponded to an Emergency situation.

\section{Results and Discussion}

\subsection{Prolonged Drought}

By applying the methodology presented in Section 2.2.1, the PDI was calculated for the Portuguese part of the Minho and Lima river basins for the period from October 1980 to September 2017. The corresponding time evolution is depicted in Figure 6. In this 
figure, for each basin (Lima and Minho, respectively in Figure 6a,b), in addition to the evolution of the PDI in the Portuguese part, the indicator for the Spanish part of the basins is also presented.

(a)

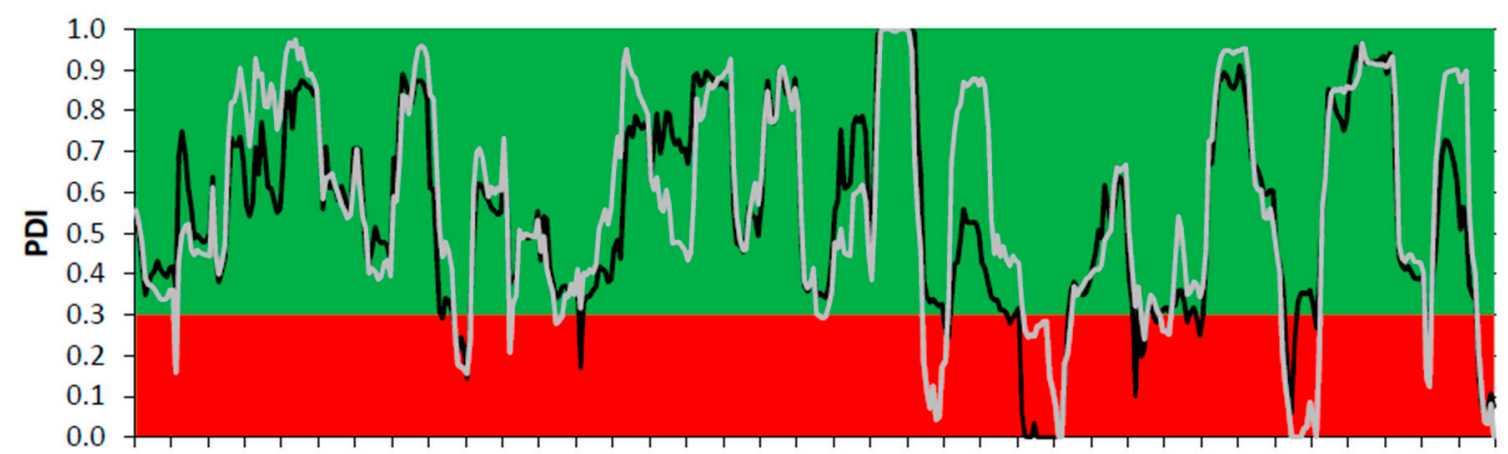

。

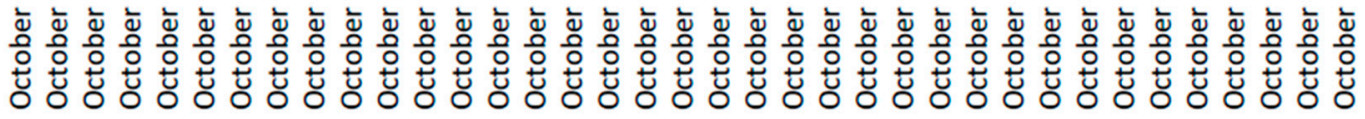

Normality Prolonged Drought Lima (Portugal) Limia (Spain)

(b)

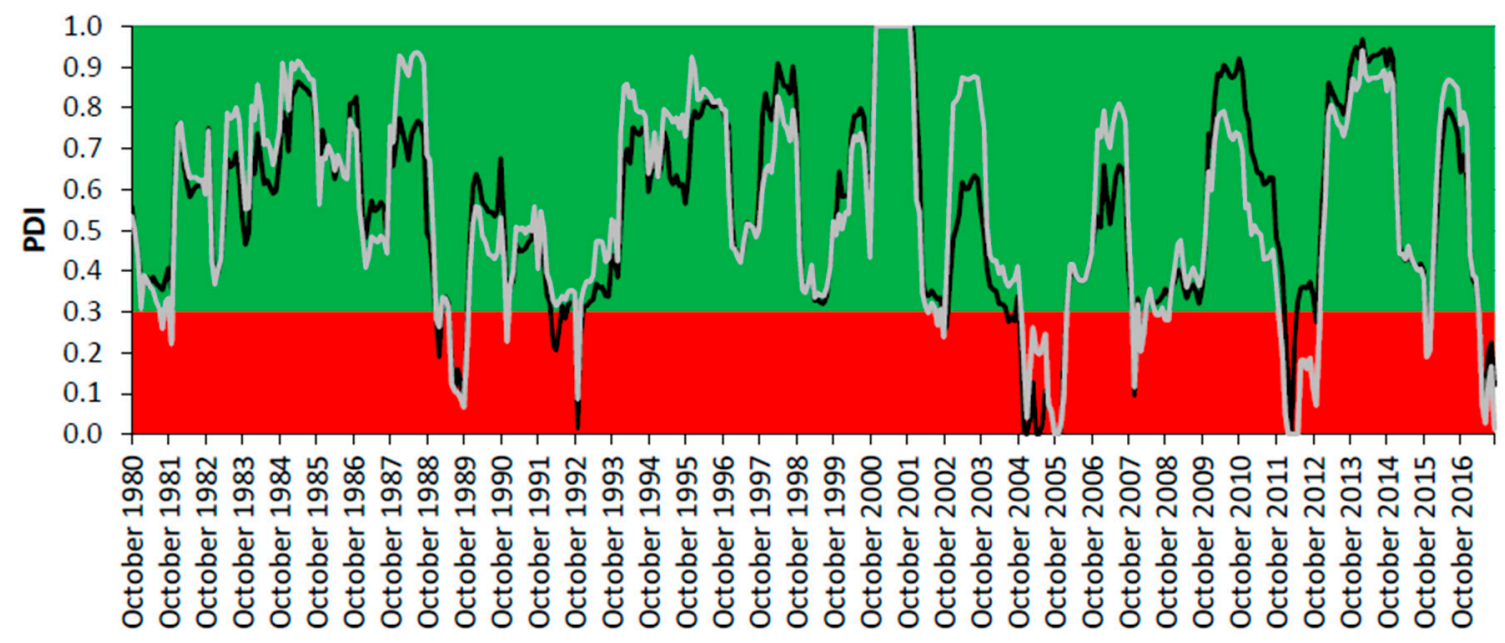

Normality Prolonged Drought Minho (Portugal) Miño-Bajo (Spain)

Figure 6. Prolonged Drought Indicator (PDI) for the period October 1980-September 2017 in (a) the Portuguese part (Lima) and the Spanish part (Limia) of the Lima river basin; and (b) in the Portuguese part (Minho) and the Spanish part (Miño-Bajo) of the Minho river basin.

Table 1 highlights the periods of months in which the situation of prolonged drought was signaled in each part of the two basins, as well as the total number of months of prolonged drought between October 1980 and September 2017.

From Table 1, it immediately follows that more months signaling prolonged drought occurred in the Spanish parts of the Minho and Lima river basins than in the respective Portuguese parts.

In general terms, it can be said that, except for the lengthy period of 16 months elapsed between 2004 and 2006, the Portuguese parts of the Minho and Lima river basins were marked by the occurrence of relatively short-term drought events (1 to 6 months), whose frequency of occurrence increased in recent years. 
Table 1. Prolonged drought events in the Portuguese and Spanish parts of the Lima and Minho river basins (period October 1980 to September 2017).

\begin{tabular}{|c|c|c|c|c|}
\hline & Lima (Portugal) & Limia (Spain) & Minho (Portugal) & Miño-Bajo (Spain) \\
\hline \multirow{17}{*}{ PD events } & February 1989 & November 1981 & January 1989-February 1989 & August 1981 \\
\hline & June 1989-November 1989 & June 1989-November 1989 & June 1989-November 1989 & November 1981 \\
\hline & November 1992 & December 1990 & March 1992-May 1992 & January 1989-February 1989 \\
\hline & October 2002-November 2002 & March 1992-May 1992 & July 1992 & June 1989-November 1989 \\
\hline & July 2004-August 2004 & May 1999-July 1999 & November 1992-December 1992 & December 1990 \\
\hline & November 2004-February 2006 & March 2002-October 2002 & October 2002-November 2002 & November 1992 \\
\hline & December 2007 & December 2004-March 2006 & July 2004-September 2004 & May 2002 \\
\hline & February 2008-March 2008 & February 2008-March 2008 & November 2004-January 2006 & August 2002 \\
\hline & June 2008-July 2008 & August 2008-November 2008 & February 2008-March 2008 & October 2002 \\
\hline & May 2009 & December 2011-December 2012 & January 2012-April 2012 & December 2004-January 2006 \\
\hline & August 2009-October 2009 & November 2015-December 2015 & November 2012 & December 2007 \\
\hline & January 2012-April 2012 & April 2017-September 2017 & November 2015-December 2015 & February 2008-March 2008 \\
\hline & November 2012 & & April 2017-September 2017 & July 2008-August 2008 \\
\hline & November 2015-December 2015 & & & October 2008-November 2008 \\
\hline & April 2017-September 2017 & & & November 2011-December 2012 \\
\hline & & & & November 2015-December 2015 \\
\hline & & & & April 2017-September 2017 \\
\hline $\begin{array}{l}\text { Total } \\
\text { months in } \\
\text { PD }\end{array}$ & 50 & 65 & 50 & 58 \\
\hline
\end{tabular}

In the Portuguese parts of the Minho and Lima river basins, the PDI values (Figure 6) show that the most severe drought episode in intensity and duration occurred between late 2004 and the beginning of 2006.

In the Spanish part of both basins, two large prolonged drought events were signaled, namely the one that occurred between the end of 2004 and the beginning of 2006 and the one that occurred between the end of 2011 and the end of 2012. In the Lima river basin (Limia), the first (2004-2006) episode was the longest, lasting 16 months. However, the later (2011-2012) event was the one with the greatest intensity. In the Minho river basin, the two events presented similar intensities and durations.

In general, despite differences in intensity and duration, there is correspondence between the periods signaled as suffering prolonged drought in the Portuguese and Spanish parts of both basins between 1980/1981 and 2016/2017.

By the observation of Figure 6, it can also be inferred that the major drought events, namely those occurring in 2004/2005-2005/2006, 2011/2012 and 2016/2017, affected both international basins. It should be noted that, in the most recent occurrence, the duration and intensity of the drought events were similar in both parts of the Minho and Lima river basins.

\subsection{Scarcity}

Figure 7 presents the evolution of the SI for the Lima and Minho River Basins, displaying both the Portuguese and the Spanish values, respectively, obtained in this study and reported in 2018 PES-MS [20]. As previously mentioned, for the Portuguese Lima river basin part, the period of analysis was from October 1993 to September 2017. For this reason, although the indicator was computed for the period from October 1980 to September 2017 for the Spanish part of the basin, only the period from October 1993 onward was presented.

Considering the period of analysis for each basin, Table 2 presents, for each part of the basins, the number of months of prevalence corresponding to each scarcity stage, as well as the respective percentages, considering the entirety of the respective period of analysis.

Through Figure 7 and Table 2, it is possible to observe that, when compared with the Portuguese part, the Spanish part of the Lima river basin had a greater exposure to scarcity situations. For the period considered (October 1993-September 2017), the Portuguese part only exhibited situations of Normality and Pre-Alert. In contrast, in the Spanish part of the 
basin, there was frequent occurrence of the Alert and Emergency statuses, particularly in the last decade of the period (2008-2017).

(a)

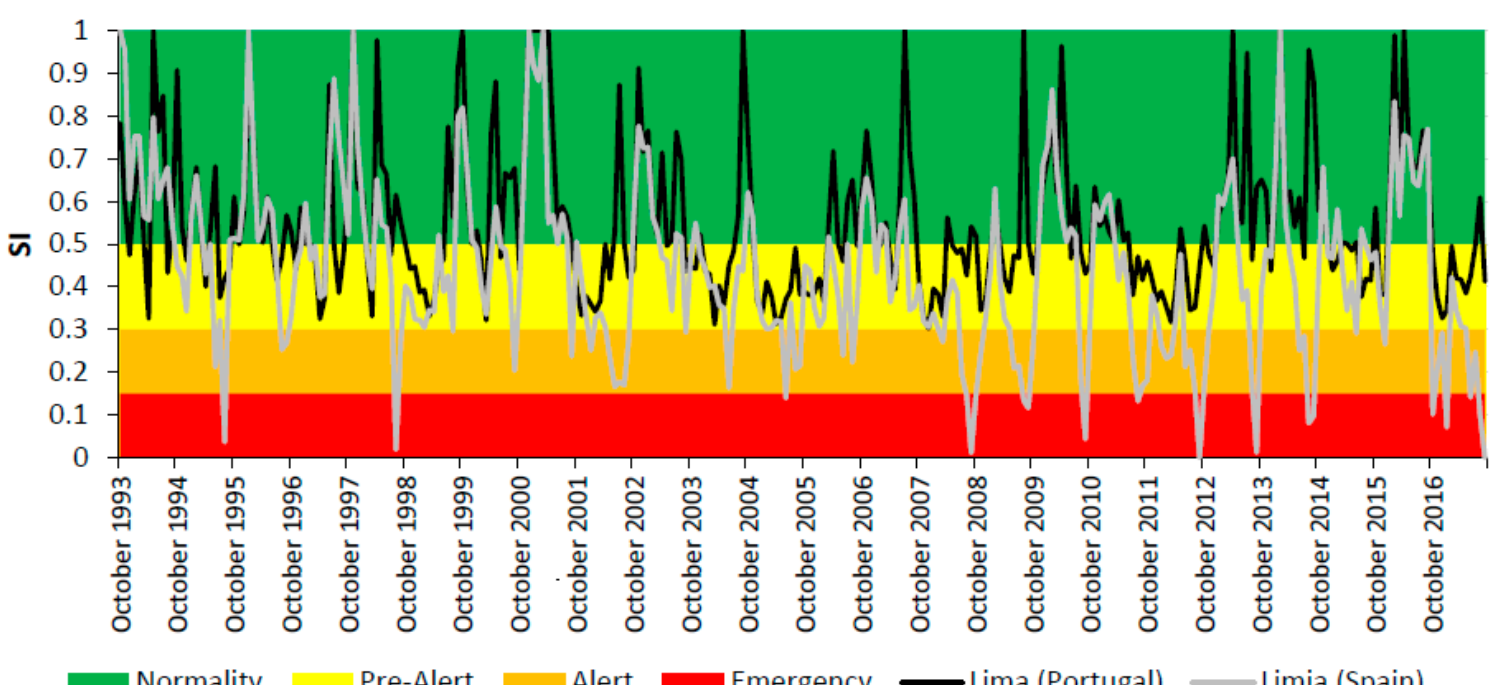

(b)

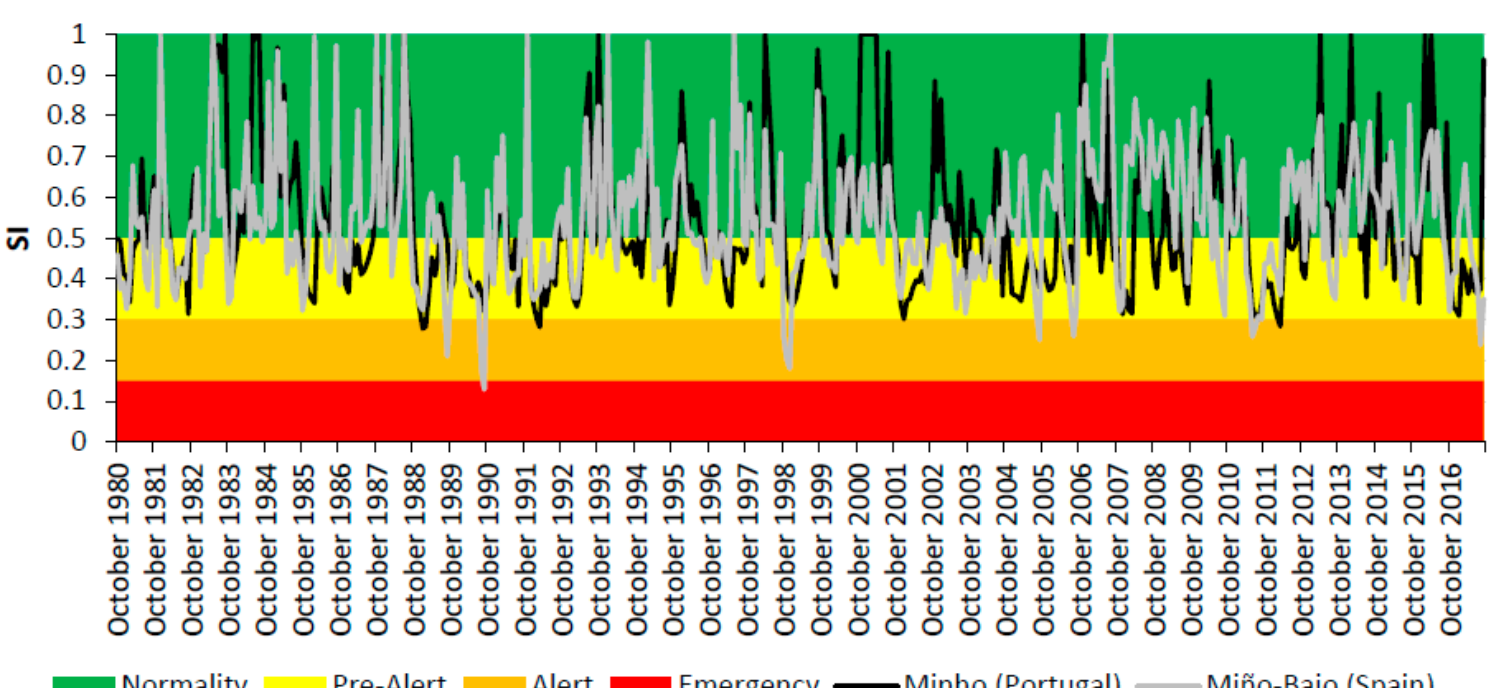

Figure 7. Scarcity Indicator (SI) in (a) the Portuguese part (Lima) and the Spanish part (Limia) of the Lima river basin for the period October 1993-September 2017; and in (b) the Portuguese part (Minho) and the Spanish part (Miño-Bajo) of the Minho river basin for the period October 1980-September 2017.

Table 2. Distribution of the scarcity status in the Portuguese and Spanish parts of the Lima and Minho river basin.

\begin{tabular}{ccccccccc}
\hline & \multicolumn{2}{c}{ Lima (Portugal) } & \multicolumn{2}{c}{ Limia (Spain) } & \multicolumn{2}{c}{ Minho (Portugal) } & \multicolumn{2}{c}{ Miño-Bajo (Spain) } \\
\hline Status & Months & $\mathbf{( \% )}$ & Months & $\mathbf{( \% )}$ & Months & $\mathbf{( \% )}$ & Months & (\%) \\
\hline Normality & 155 & 53.8 & 109 & 37.8 & 223 & 50.2 & 248 & 55.9 \\
Pre-Alert & 133 & 46.2 & 116 & 40.3 & 216 & 48.7 & 188 & 42.3 \\
Alert & 0 & 0.0 & 45 & 15.6 & 5 & 1.1 & 7 & 1.6 \\
Emergency & 0 & 0.0 & 18 & 6.3 & 0 & 0.0 & 1 & 0.2 \\
\hline
\end{tabular}

With regard to the Minho river basin, both parts had low exposure to scarcity situations, presenting very few cases falling under the scope of the Alert status, between October 1980 
and September 2017. It should also be noted that the Spanish part, throughout the analysis series, presented only one month in Emergency status.

\section{Conclusions}

To minimize water conflicts and prevent drought- and scarcity-related impacts on international river basins, it is essential that both countries have similar planning and management approaches. In this regard, Portugal and Spain are not yet in similar stages. Notably, the definition of comparable drought indicators to be applied in common by the two countries in the shared river basins is missing.

In this context, the goal of the present work was the definition of common drought indicators in the shared river basins as a tool for the better coordination of drought and water scarcity management in the Iberian Peninsula. For this purpose, examining the Minho and Lima river basins as case study, this work presented the definitions of the indicators in the Portuguese part of the Minho and Lima river basins similar to those defined in the Spanish part of the two basins, namely the Prolonged Drought and Scarcity indicators.

The resulting indicators showed that, in terms of prolonged drought and despite different intensities and durations, there was a general coincidence between the periods of prolonged drought in the Portuguese and Spanish parts of the Lima and Minho river basins between 1980/1981 and 2016/2017, with the major drought events being signaled in the two parts of each basin.

Concerning scarcity situations, both the Portuguese and Spanish parts of the Minho river basins and the Portuguese part of the Lima river basin have low exposure to scarcity situations. The only exception is the Spanish part of the Lima river basin, which has a high level of exposure to this situation.

Based on the results presented, namely due to the apparent adequacy of the indicators obtained for Spanish and Portuguese parts of the Minho and Lima river basins, it can be concluded that the general Spanish methodology presented may be considered to be a valid starting point for the Portuguese part of Minho and Lima river basins and that it has also the potential to be applied in the others Portuguese basins.

The advantage of using these indicators instead of the use of more conventional singular indicators, such as the SPI or other hydrological indicators, corresponds to the fact of diagnosis and indicator results being more clearly comparable between the different basins, despite their proper characteristics. Moreover, the definition of similar indicators has extreme importance for transboundary drought and scarcity management since, common definitions enable the common characterization and comparison of droughts and scarcity events in the Portuguese and Spanish parts of the shared river basins. That may allow the common planning, management and monitoring of droughts and scarcity situations between the two countries.

In addition to a better integration of both countries with WFD principles and goals, the drought and scarcity common indicators' definitions and management shall lead to the improvement of the Albufeira Convention implementation by contributing not only to the envisaged redefinition of the MFR but also to an agreement on the definition of environmental flows for common stretches of the transboundary rivers.

Nevertheless, it should be emphasized that some work remains to be developed to improve the current system of indicators to be used in common by the two countries. In fact, despite being in a way quite integrated with the WFD (distinguishing prolonged drought situations from scarcity situations), the use of the Spanish system of indicators has some recognized limitations, cautions and reserves that must be considered [34], namely, concerning the PDI. In the Spanish system, the definition of the PDI only considers the intensity and not the duration of the events; the arbitrary definition of the threshold for prolonged drought is equal to an indicator value of 0.30 . This definition should be agreed with Portugal, because the measures envisaged to be applied by Spain for prolonged drought - the call in Article 4.(6) of the WFD and reduction of environmental flows-may not only affect Portugal but also in fact themselves constitute the consequences of prolonged 
drought events. Therefore, the management of prolonged drought situations should be performed in order to achieve a maximum delay on the use of Article 4.(6) and on the reduction of the environmental flows, which ought not to be exacerbated.

Author Contributions: Conceptualization, R.M., M.C. and J.M.; methodology development and application, M.C.; result analysis and validation, R.M., M.C. and J.M.; writing-original draft preparation, M.C. and J.M.; writing-review and editing, R.M., M.C. and J.M.; supervision, R.M. All authors have read and agreed to the published version of the manuscript.

Funding: This research was supported by the RISC_ML project (reference: 0034_RISC_ML_6_E), co-funded by the European Regional Development Fund (ERDF) through the Interreg V-A SpainPortugal Program (POCTEP) 2014-2020.

Institutional Review Board Statement: Not applicable.

Informed Consent Statement: Not applicable.

Data Availability Statement: The data used in this study are available in the publicly accessible repositories: SNIRH database (https: / / snirh.apambiente.pt/, accessed on 20 October 2021) and SAIH Miño Sil (http:/ / saih.chminosil.es/, accessed on 20 October 2021).

Conflicts of Interest: The authors declare no conflict of interest.

\section{References}

1. Van Lanen, H.A.; Vogt, J.V.; Andreu, J.; Carrão, H.; De Stefano, L.; Dutra, E.; Feyen, L.; Forzieri, G.; Hayes, M.; Inglesias, A.; et al. Climatological risk: Droughts. In Science for Disaster Risk Management 2017: Knowing Better and Losing Less, 1st ed.; Poljansek, K., Marin Ferrer, M., De Groeve, T., Clark, I., Eds.; Publications Office of the European Union: Luxembourg, 2017; ISBN 978-92-79-60679-3.

2. Kalis, G. Droughts. Annu. Rev. Environ. Resour. 2008, 33, 85-118. [CrossRef]

3. Van Loon, A.F.; Van Lanen, H.A. Making the distinction between water scarcity and Drought using an observation-modeling framework. Water Resour. Res. 2013, 49, 1483-1502. [CrossRef]

4. Vivas, E. Assessment and Management of Drought and Scarcity Situations. Application to the Guadiana Case. Ph.D. Thesis, Faculty of Engineering of the University of Porto, Porto, Portugal, 2011. (In Portuguese).

5. Wilhite, D.A.; Sivakumar, M.V.; Pulwarty, R. Managing drought risk in a changing climate: The role of national drought policy. Weather. Clim. Extrem. 2014, 3, 4-13. [CrossRef]

6. Hervás-Gámez, C.; Delgado-Ramos, F. Drought Management Planning Policy: From Europe to Spain. Sustainability 2019, 11, 1862. [CrossRef]

7. European Commission. Directive 2000/60/EC of the European Parliament and of the Council of 23 October 2000 establishing a framework for Community action in the field of water policy. L 327 2000, 01-0073. In Official Journal of the European Communities, L327/1; European Parliament and the Council of the European Union: Brussels, Belgium, 2000. Available online: https:/ / eur-lex. europa.eu/legal-content/EN/TXT/?uri=CELEX:32000L0060 (accessed on 20 October 2021).

8. Zikos, D.; Hagedorn, K. Competition for Water Resources from the European Perspective. In Competition for Water Resources: Experiences and Management Approaches in the US and Europe, 1st ed.; Ziolkowska, J., Peterson, J., Eds.; Elsevier: Cambridge, MA, USA, 2017; pp. 19-35. [CrossRef]

9. European Commission. Communication from the Commission to the European Parliament and the Council-Addressing the Challenge of Water Scarcity and Droughts in the European Union. COM(2007) 414 Final; Commission of the European Communities: Brussels, Belgium, 2007. Available online: https: / / eur-lex.europa.eu/legal-content/EN/ALL/?uri=CELEX\%3A52007DC0414 (accessed on 20 October 2021).

10. European Commission. Communication from the Commission to the European Parliament, the Council, the European Economic and Social Committee and the Committee of the Regions-Report on the Review of the European Water Scarcity and Droughts Policy. COM(2012) 672 Final; European Commission: Brussels, Belgium, 2012. Available online: https://eur-lex.europa.eu/legal-content/EN/TXT/ ?uri=CELEX:52012DC0672 (accessed on 20 October 2021).

11. European Commission. Communication from the Commission to the European Parliament, the Council, the European Economic and Social Committee and the Committee of the Regions-Forging a Climate-Resilient Europe-the New EU Strategy on Adaptation to Climate Change. $\operatorname{COM(2021)} 82$ Final; European Commission: Brussels, Belgium, 2021. Available online: https://eur-lex.europa.eu/legal-content/ EN/TXT/?uri=COM:2021:82:FIN (accessed on 20 October 2021).

12. European Commission. Report from the Commission to the European Parliament and the Council-Third Follow up Report to the Communication on Water Scarcity and Droughts in the European Union COM (2007) 414 Final. COM(2011) 133 Final; European Commission: Brussels, Belgium, 2011. Available online: https://eur-lex.europa.eu/legal-content/EN/TXT/?uri=CELEX: 52011DC0133 (accessed on 20 November 2021). 
13. Maia, R.; Vicente-Serrano, S. Drought Planning and Management in the Iberian Peninsula. In Drought and Water Crises: Integrating Science, Management, and Policy, 2nd ed.; Wilhite, D., Pulwarty, R., Eds.; CRC Press: Boca Raton, FL, USA, 2017; pp. 481-506. [CrossRef]

14. DR. Resolution of the Assembly of the Republic $n^{\circ}$ 66/99-Convention on Cooperation for the Protection and Sustainable Use of the Waters of the Portuguese-Spanish River Basins and the Additional Protocol. In Diário da República $n^{\circ}$ 191/1999, Série I-A de 1999-08-17 (Portuguese Government Official Journal); Assembleia da República: Lisboa, Portugal, 1999. Available online: https:/ / dre.pt/dre/detalhe/resolucao-assembleia-republica/66-1999-434660 (accessed on 20 November 2021). (In Portuguese)

15. DR. Resolution of the Assembly of the Republic no. 62/2008-Protocol of Review of the Convention on Cooperation for the Protection and Sustainable Use of the Waters of the Portuguese-Spanish River Basins (Albufeira Convention) and the Additional Protocol. In Diário da República $n^{\circ}$ 222/2008, Série I de 2008-11-14 (Portuguese Government Official Journal); Assembleia da República: Lisboa, Portugal, 2008; pp. 7961-7969. Available online: https://dre.pt/dre/detalhe/resolucao-assembleia-republica/62-2008-43 9852 (accessed on 20 November 2021). (In Portuguese)

16. Chainho, P.; Martínez-Fernández, J. Iberian waters under European protection: Soft water in hard stone? In Proceedings of the X Congresso Ibérico de Gestão e Planeamento da Água, Coimbra, Portugal, 6-8 September 2018; ISBN 978-84-944788-5-7. (In Portuguese and Spanish).

17. Arca, I. The Albufeira Convention: An analysis on the occasion of the Twentieth Anniversary of its Adoption. Rev. Catalana De Dret Ambient. 2019, 10, 1-38. (In Spanish) [CrossRef]

18. Estrela, T.; Sancho, T. Drought management policies in Spain and the European Union: From traditional emergency actions to Drought Management Plans. Water Policy 2016, 18, 153-176. [CrossRef]

19. Spanish Government. Order TEC/1399/2018, of November 28, approving the review of the special drought plans. In BOE núm. 311, de 26 de Diciembre de 2018 (Spanish Government Official Journal); Ministerio para la Transición Ecológica: Madrid, Spain, 2018. Available online: https:/ / www.boe.es/diario_boe/txt.php?id=BOE-A-2018-17752 (accessed on 20 November 2021). (In Spanish)

20. Confederación Hidrográfica del Miño-Sil. Special Plan of Action in Situations of Alert and Eventual Drought of the Spanish Part of the Miño-Sil River Basin District: Memory; CHMiño-Sil: Ourense, Spain, 2018. Available online: https://www.chminosil.es/ es/chms/planificacionhidrologica/nuevo-plan-especial-de-sequia/plan-especial-en-situaciones-de-alerta-y-eventual-sequiade-la-demarcacion-hidrografica-del-mino-sil-pes-version-definitiva-aprobada-y-vigente (accessed on 20 November 2021). (In Spanish)

21. Comissão Permanente de Prevenção, Monitorização e Acompanhamento dos Efeitos de Seca. Prevention, Monitoring and Contingency Plan for drought Situations. 2017. Available online: https:/ /apambiente.pt/agua/plano-de-prevencao-monitorizacao-econtingencia-para-situacoes-de-seca (accessed on 20 November 2021). (In Portuguese).

22. Maia, R. The Guadiana Case Study. In GAR Special Report on Drought 2021; United Nations Office for Disaster Risk Reduction: Geneva, Italy, 2021. Available online: https:/ / www.undrr.org/publication/guadiana-case (accessed on 20 December 2021).

23. Expresso. The Water No Longer Flows in the River: Images of Desolation Caused by Drought and Spain. Available online: https: / / expresso.pt/sociedade/2019-10-12-A-agua-ja-nao-corre-no-rio-as-imagens-da-desolacao-provocada-pela-secae-por-Espanha (accessed on 20 October 2021). (In Portuguese)

24. Ministério do Ambiente e da Ação Climática. Flows of the Tejo River. Available online: https://www.portugal.gov.pt/pt/gc22/ comunicacao/comunicado?i=caudais-do-rio-tejo (accessed on 20 December 2021). (In Portuguese)

25. Do Ó, A. Transboundary Drought Management in the Guadiana: Applying the Conflict Risk Index. In Proceedings of the $5^{\circ}$ Congresso Internacional de Ordenamento do Território-Gestão Partilhada de Recursos Hídricos Internacionais, Lisboa, Portugal, 27-28 October 2010.

26. RISC_ML: Prevention of Flood and Drought Risks in the Minho-Lima International River Basins. Available online: http: / / risc-ml.eu (accessed on 20 December 2021).

27. Agência Portuguesa do Ambiente. Minho and Lima River Basin Management Plan (RBD1) 2016-2021. Part 2-Characterization and Diagnostics (Annexes); APA: Lisboa, Portugal, 2016. Available online: https:/ / apambiente.pt/agua/2o-ciclo-de-planeamento-20 16-2021 (accessed on 20 November 2021). (In Portuguese)

28. Ministério para la Transición Ecológica. Technical Instruction for the Preparation of Special Drought Plans and the Definition of the Global System of Indicators of Prolonged Drought and Scarcity; MITECO: Madrid, Spain, 2017. Available online: https://www.miteco.gob. es/es/agua/participacion-publica/PP-Agua-Orden-instruccion-tecnica-elaboracion-planes-especiales-sequia.aspx (accessed on 20 November 2021). (In Spanish)

29. Spanish Government. Real Decreto 907/2007-Hydrological Planning Regulation. In BOE Núm. 162 , de 7 de Julio de 2007 (Spanish Government Official Journal); Ministerio de Medio Ambiente: Madrid, Spain, 2007. Available online: https://www.boe.es/buscar/ doc.php?id=BOE-A-2007-13182 (accessed on 20 November 2021). (In Spanish)

30. McKee, T.; Doesken, N.; Kleist, J. The relationship of drought frequency and duration to time scales. In Proceedings of the Eight Conference on Applied Climatology, Anaheim, CA, USA, 17-22 January 1993.

31. Agência Portuguesa do Ambiente. Douro River Basin Management Plan (RBD3) 2016-2021. Part 2-Characterization and Diagnostics (Annexes); APA: Lisboa, Portugal, 2016. Available online: https://apambiente.pt/sites/default/files/_SNIAMB_Agua/DRH/ PlaneamentoOrdenamento/PGRH/2016-2021/PTRH3/PGRH_2_RH3_Parte2_Anexos.pdf (accessed on 20 November 2021). (In Portuguese) 
32. Agência Portuguesa do Ambiente. Tejo and Ribeiras do Oeste River Basin Management Plan (RBD5) 2016-2021. Part 2-Characterization and Diagnostics (Annexes); APA: Lisboa, Portugal, 2016. Available online: https://apambiente.pt/sites/default/files/_SNIAMB_ Agua/DRH/PlaneamentoOrdenamento/PGRH/2016-2021/PTRH5A/PGRH_2_RH5A_Parte2_Anexos.pdf (accessed on 20 November 2021). (In Portuguese)

33. Agência Portuguesa do Ambiente. Guadiana River Basin Management Plan (RBD7) 2016-2021. Part 2-Characterization and Diagnostics (Annexes); APA: Lisboa, Portugal, 2016. Available online: https://apambiente.pt/sites/default/files/_SNIAMB_Agua/DRH/ PlaneamentoOrdenamento/PGRH/2016-2021/PTRH7/PGRH_2_RH7_Parte2_Anexos.pdf (accessed on 20 November 2021). (In Portuguese)

34. Fundación Nueva Cultura del Agua (FNCA). FNCA Observations to the "Technical Instruction for the Preparation of Special Drought Plans and the Definition of the Global System of Indicators of Prolonged Drought and Scarcity"; FNCA: Zaragoza, Spain, 2018. (In Spanish) 